\title{
Aesthetics of Virtual: The Development Opportunities of Virtual Museums in Indonesia
}

\author{
Ayu Soraya ${ }^{1}$, Yusup Sigit Martyastiadi ${ }^{2}$ \\ ${ }^{1}$ Visual Communication Design, Universitas Potensi Utama; J1. KL Yos Sudarso Km 6,5 No 3A, \\ Tanjung Mulia, Medan Deli, Medan City, North Sumatra 20241 \\ ${ }^{1}$ Doctoral Program, Graduate School of Indonesia Institute of the Arts Yogyakarta \\ ${ }^{2}$ Interaction Design, Faculty of Art \& Design, Universitas Multimedia Nusantara; J 1. Scientia \\ Boulevard, Gading, Kec. Serpong, Tangerang, Banten 15227 \\ Email: 'ayusoraya@potensi-utama.ac.id; '2yusup.martyastiadi@umn.ac.id
}

\begin{abstract}
The Covid-19 pandemic requires us to carry out physical and social distancing. It is undeniable, this also has an impact on government policy to close tourist destinations, including museums. Currently, sophisticated 3D visualization technology provides the potential for the development of virtual museums. The virtual museums were developed for giving the experience of the visiting museum in the digital world as a distance learning. This application can provide immersion through interactivity while exploring virtual museums. Basically, this article explains the aesthetic investigations in some virtual museums. The researchers describe the aesthetic of each sampled virtual museums projects. The literature synthesis of several virtual museums projects is expected to be able to give an idea of the potential development of virtual museums in Indonesia. The aesthetics of virtual elements could be used as a recommendation for museum conservator for the development of prospective Indonesian virtual museums. Furthermore, the aesthetics of virtual in digital museums provide opportunities to present virtual museums exploration experiences.
\end{abstract}

Keywords: virtual museums, aesthetics of virtual, Indonesian museum, virtual experiences

Estetika Virtual: Peluang Perkembangan Museum Virtual di Indonesia

Abstrak

Pandemi Covid-19 mengharuskan kita melakukan jarak fisik dan sosial. Tak bisa dipungkiri, hal ini juga berdampak pada kebijakan pemerintah untuk menutup destinasi wisata, termasuk museum. Saat ini, teknologi visualisasi 3D yang canggih memberikan potensi untuk pengembangan museum virtual. Museum virtual dikembangkan untuk memberikan pengalaman mengunjungi museum di dunia digital sebagai pembelajaran jarak jauh. Aplikasi ini dapat memberikan immersion melalui interaktivitas sambil menjelajahi museum virtual. Pada dasarnya, artikel ini menjelaskan investigasi estetika di beberapa museum virtual. Para peneliti mendeskripsikan estetika dari setiap proyek museum virtual yang dijadikan contoh. Sintesis literatur dari beberapa proyek museum virtual diharapkan dapat memberikan gambaran tentang potensi perkembangan museum virtual di Indonesia. Estetika unsur virtual dapat dijadikan sebagai rekomendasi bagi konservator museum untuk pengembangan museum virtual Indonesia yang akan datang. Selain itu, estetika virtual dalam museum digital memberikan peluang untuk menghadirkan pengalaman eksplorasi museum virtual.

Kata kunci: museum virtual, estetika virtual, museum Indonesia, pengalaman virtual 


\section{INTRODUCTION}

Indonesia has a variety of historical and cultural heritage to be proud of. A means is needed to store historical or cultural heritage so that the nation's future generations can inherit it. The museum is one of the tourist objects to add insight and knowledge in which there are objects of the cultural heritage of the past. The museum's function is collecting, recording, maintaining, and exhibiting collections to develop insight, knowledge, education, and research sources for the public (Direktorat Museum, 2009). Conventional museums require visitors to come directly to the museum in order to explore cultural relics of the past. The presence of visitors is a critical point to feel the aesthetics when exploring the museum to bring memories of the past.

The outbreak of the Covid-19 outbreak in Indonesia has brought many changes to people's behaviour. Previously, the community was free to carry out activities outside the home. However, with this pandemic, people are in a condition of physical distancing following recommendations from the government. This has become a new life activity in the community by getting used to doing online activities. In addition, the covid-19 pandemic resulted in the closure of tourist attractions in Indonesia by the government, including museums. Of course, this is a challenge for museum management to overcome this problem if this pandemic runs for a long time. One of the most relevant solutions is to utilize technology to enjoy museum exploration still even though they are in their respective homes.

Technological developments through increasingly sophisticated 3D visualization provide the potential for the development of virtual museums, especially in Indonesia. In foreign countries, many virtual museums have been developed. The objectives of developing virtual museums vary according to the needs of the museum. One museum in Germany that has developed a virtual museum is The Imperial Cathedral in Königslutter. This museum creates virtual reality using 3600 3D visualizations with the concept of Panoramic Photography to provide deeper interactivity facilities for users to explore real spaces in the virtual world (Walmsley \& Kersten, 2020).

Based on some literature, the development of virtual museums abroad focuses on artefacts and the museum's integrity both in terms of visitor experience and exhibitions. Previtali (2019) shows one example of a virtual museums development that focuses on artefacts, namely The San Clemente Site In Albenga (Italy). The virtual museums developed by the museum manager aims to increase awareness of the vulnerability of archaeological sites. The concept used by this museum is the development of virtual notebooks, which experts and tourists can use to access virtual site information.

In an art museum, the development of the digital world can change artists' perspective to express their art forms through exhibitions in new ways by the 
development of the digital world. Some museums have designed virtual exhibits to make visitor reach wider and more accessible. By leveraging technology, works of art are starting to take advantage of artificial intelligence (AI) is facing new challenges in the future by presenting new ways to view art (Giannini \& Bowen, 2019). Virtual museums can overcome the limitations of physical space in exhibiting museum objects. Empler (2018) said that virtual museums could present exhibition spaces with deeper routes, content and approaches through virtual spaces that have been designed.

Virtual museums, in their application, can take advantage of augmented reality technology. Augmented reality is used to create an augmented heritage designed in the form of a video that is applied to classical performance spaces. This concept brings back cultural heritage that is considered classic, using technology to attract the younger generation's attention (Maniello, 2016). This design aims to explore the potential for debate between space, technology, and narrative structure. The visual structure supports sound and vice versa, where "a plurality of technological and communication devices is available". Augmented reality presents a new experience for users to enjoy museum objects still even though they do not have direct contact. This can generate immersion for each visitor to present a new meaning for each individual.

Technology can make it easier for the next generation to obtain information and enhance cultural experiences regarding past objects that become cultural heritage. One of the basics of developing virtual museums is the physical limitations in accessing information about objects. The presence of virtual museums using the concept of virtual reality can provide users with real experiences regarding the historical experience they want to see. This concept invites visitors to enter a virtual world and create their own interactive stories. Hereniko (2018) emphasizes that the focus of virtual museums is not on the object but instead on the creation of memories, feelings, and emotions. The development of virtual museums does not mean eliminating physical museums because basically the presence of virtual museums is not a competitor for physical museums. However, their presence can complement each other; things that cannot be realized in a physical museum could be exhibited in virtual museums and vice versa (Gutowski, 2019). Some museums design virtual museums to attract visitors. The need for information on historical artefacts cannot be fulfilled in a physical museum. With virtual museums, information about historical artefacts can be described in more detail to meet the information needs needed by visitors. The interaction made by visitors will leave a profound experience of the museum. 


\section{MATERIALS AND METHOD}

This study employs kinds of literature review, and existing projects interpretation uses the MDA approach (Hunicke et al., 2004; LeBlanc, 2004). According to the MDA approach, the authors will describe each component, such as mechanics, dynamics, and aesthetics for existing projects. The mechanics describe tool requirement (hardware and software). The dynamics explains interaction and play experiences. The last, the aesthetics depict sensation that users felt by their sensory and kinesthetic trigger. By observing the existing virtual museum projects, the authors list the MDA approach for each project. In the following step, the authors conduct a synthesis to investigate potential opportunities for virtual museums development in Indonesia.

\section{RESULTS}

There are five virtual museums (VMs) projects that used for interpretation. Those projects were developed in Germany, Italy, Netherlands, and England. Table 1. below indicates the MDA approach through five VMs projects.

Table 1. MDA Approach of Existing Virtual Museums Projects

\begin{tabular}{|c|c|c|c|c|}
\hline No. & $\begin{array}{c}\text { Name of } \\
\text { project }\end{array}$ & Mechanics & Dynamics & Aesthetics \\
\hline 1. & $\begin{array}{l}\text { The Imperial } \\
\text { Cathedral in } \\
\text { Königslutter, } \\
\text { (Walmsley \& } \\
\text { Kersten, 2020) }\end{array}$ & $\begin{array}{ll} & 360^{\circ} \text { panoramic images } \\
& \text { generator (PTGui) } \\
\text { - } & \text { Riegl VZ-400, Zoller + } \\
& \text { Fröhlich IMAGER } 5006 \\
& \text { laser scanner } \\
\text { - } & \text { AutoCAD, Autodesk } \\
& \text { Maya, UE4 game engine } \\
\text { - } & \text { HTC Vive Pro (VR } \\
\text { headset) }\end{array}$ & $\begin{array}{l}\text { - Interactivity environment, } \\
\text { switching between } \\
\text { digitized environment and } \\
\text { captured real environment } \\
\text { - Freedom to make } \\
\text { exploration } \\
\text { - Scenario: explore the } \\
\text { cathedral } \\
\text { - https://www.koenigslutter- } \\
\text { kaiserdom.de/ } \\
\text { virtuelleTour/ } \\
\text { tour.html }\end{array}$ & 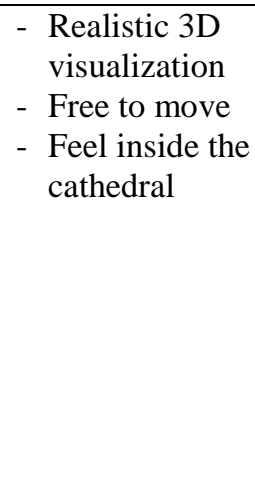 \\
\hline 2. & $\begin{array}{l}\text { The San } \\
\text { Clemente Site } \\
\text { In Albenga } \\
\text { (Italy), } \\
\text { (Previtali, 2019) }\end{array}$ & $\begin{array}{l}\text { - } 360^{\circ} \text { panoramic images } \\
\text { generator } \\
\text { - } \text { TLS and UAV } \\
\text { equipment } \\
\text { - } \text { WebGL, OpenGL } \\
\text { - }\end{array}$ & $\begin{array}{l}\text { - Various combinations of } \\
\text { photographs and 3D } \\
\text { visualization with } \\
\text { informative contents } \\
\text { - Scenario: explore the site } \\
\text { - Archaeologists and } \\
\text { practitioners } \rightarrow \\
\text { interactivity in Web } \\
\text { (Desktop) } \\
\text { - Tourists and citizens } \rightarrow \\
\text { interactivity in Web } \\
\text { (mobile) }\end{array}$ & $\begin{array}{l}\text { - Realistic 3D } \\
\text { visualization } \\
\text { - Get historical } \\
\text { information }\end{array}$ \\
\hline 3 & $\begin{array}{l}\text { Batavia } 1627 \text { in } \\
\text { Virtual Reality } \\
\text { (Westfries } \\
\text { Museum }\end{array}$ & $\begin{array}{l}\text { - VR headset } \\
\text { - } 3 \mathrm{D} \text { Blender software }\end{array}$ & $\begin{array}{l}\text { - The narrative is linear } \\
\text { - Scenario: explore the } \\
\text { surrounding environment }\end{array}$ & 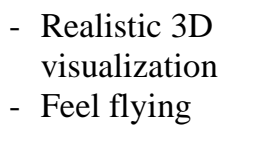 \\
\hline
\end{tabular}


Netherlands, https://wfm.nl/b atavia-1627vr)

4. Viking VR, (Schofield et al., 2018)

5. Geguti Palace in Kutaisi,

Georgia, (Ferrari \& Medici, 2017)
- Android smartphone with handmade VR cardboard, including plastic lenses

- 3D Blender software of Batavia in 1627

(Sergeant, 2020)

- Intersections between pedagogy, art, and technology and influences socially and politically

- Interactivity using VR headset

- Scenario: designing a VR experience to form part of Viking's life

- Engaging with a particular historical event in Torksey

- The narrative is linear

- Scenario: explore the site

- $360^{\circ}$ navigable
- Realistic 3D visualization

- Capturing the harshness of the climate, its effect on the culture and lifestyle of the period

- Realistic 360 3D visualization

- Get historical information (UI \& text)
- X-PAD Office FUSION

by Geomax,

- $360^{\circ}$ panoramic images generator

- Portable HMD

- Android smartphone with handmade VR cardboard, including plastic lenses

- Affinity software

The five VMs projects are listed in Table 1., mostly digitized archaeological sites and reconstructed the life environment of historical events. Mechanically, all VMs use manufactured product of head-mounted displays (HMD) or handmade HMD, cardboard for instance (as shown in Figure 1.), and including android OS based. The five projects were conducted using 3D software, and some add $360^{\circ}$ panoramic photographs/images as supplements. Moreover, two projects engage laser scanner for generating $3 \mathrm{D}$ assets.
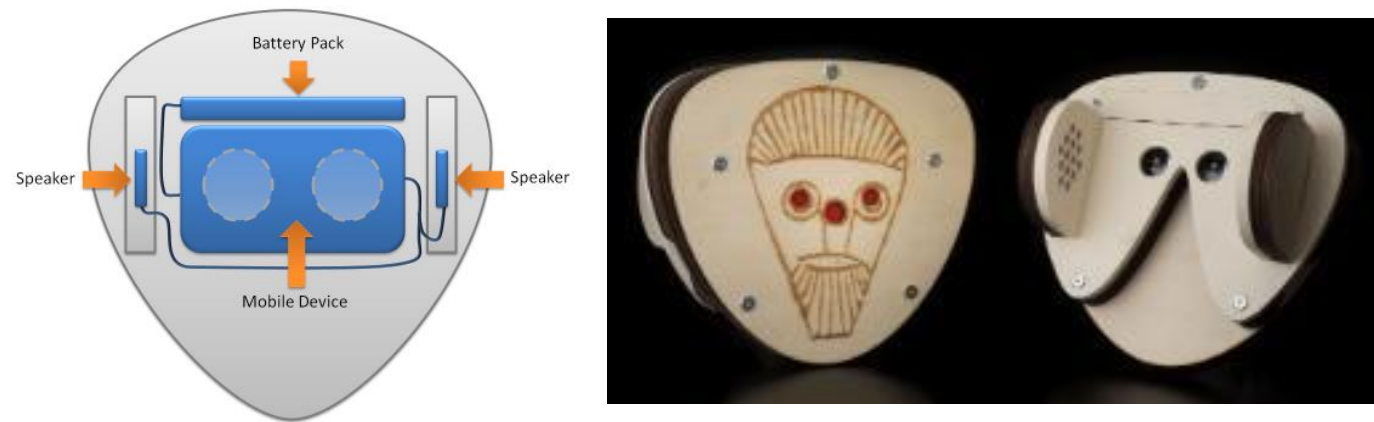

Figure 1. VR Cardboard Headset of Viking VR

Source: Schofield et al., 2018 
As a dynamics approach, half of the projects employ linear narrative and interaction, Batavia 1627 in Virtual Reality and Geguti Palace in Kutaisi. The rest more dynamics interaction, such as the projects of The Imperial Cathedral in Königslutter, The San Clemente Site In Albenga, and Viking VR. According to Table 1., generally, all projects are exploring the archaeological site. In addition, Batavia 1627 in Virtual Reality and Viking VR has given the experience of the living environment of a particular historical event.

The last approach, the aesthetics, are shown by the sense of 3D realistic visualization. The $3 \mathrm{D}$ environment is developed to resemble estimates of original conditions in the past - the interpretation based on visual references and the ruins of historical buildings. As a result, most of the projects present the condition of immersion. The users feel that they inside the virtual archaeological building. On the other hand, the Batavia 1627 project given the sensation of flying due to the camera perspective of bird eyes (as shown in Figure 2.). Despite the visual sensation that the user felt, there is also historical information about the archaeological site in the $2 \mathrm{D}$ text user interface.

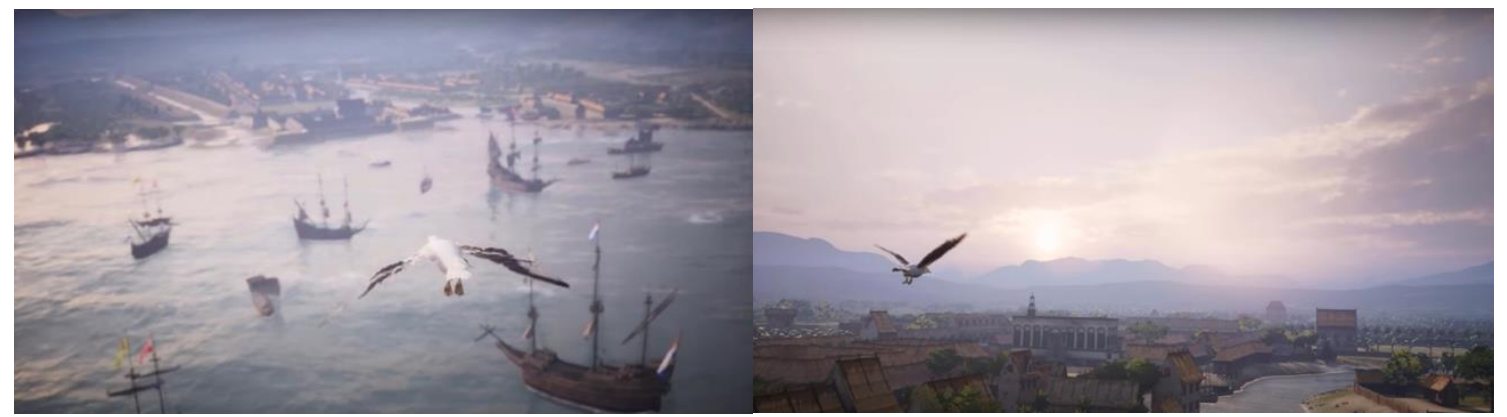

Figure 2. Trailer of Batavia $1627 \mathrm{VR}$

Source: Westfries Museum, 2020 - https:/www.youtube.com/watch?v=EGQiYHrNj7o

\section{DISCUSSION}

In the digital era, Kaun \& Uldam (2018) state that artistic performing changes as artists consider the changing environment. They offer alternative ways to understanding the aesthetics of artwork and cultural artefacts. In the digital world, everyone interacts with the artwork and is included in the artwork's discussion, especially in visiting virtual museums. Bowen \& Giannini (2014) emphasize that the reality of digital life now has no boundaries; real and virtual overlap each other where everyone is connected to the internet technology and the interface of several applications.

This technological development provides an advantage to develop a virtual museum. Sylaiou et al. (2005) add that the emerging tools and technologies help museum curators conduct digital exhibitions. The benefits of the virtual exhibition 
are innovative, cost-effective, and interested for prospective visitors, especially from the far way from the museum itself. Virtual museum visitors can interact with museum artefacts without any acts of vandalism. In other words, they can virtually touch historical works of art. Visitors can also explore the virtual museum conveniently and get information visually, auditory, and text when interacting with these artefacts. The virtual museums' visitors experience the past concerning artefacts and historical events. They are immersed in the scenarios developed by virtual museums conservators. This interaction can be done inside the museum (provided with equipment to try out the virtual museums) or online from each visitor's home. However, online virtual museums have the consequence that there is a change in behaviour in visiting museums.

According to the MDA approach of five existing projects as shown in Table 1. above, some points can be used to recommend VMs development in Indonesia. Table 2. describes the recommendation for VMs Development in Indonesia.

Table 2. Recommendation for VMs Development in Indonesia

\begin{tabular}{|c|c|c|}
\hline No. & Item & Recommendation \\
\hline 1. & Technology & $\begin{array}{l}\text { - Manufactured product of HMD (ex. Oculus Rift, HTC } \\
\text { Vive) } \\
\text { - VR Glasses with a smartphone (ex. Samsung VR } \\
\text { Gear) } \\
\text { - Handmade Cardboard VR with smartphone }\end{array}$ \\
\hline 2. & Deployment & $\begin{array}{l}\text { - Inside the museum (Onsite VMs) } \\
\text { - Online VMs (WebGL, application) }\end{array}$ \\
\hline 3. & Content & $\begin{array}{l}\text { - Historical artefacts exhibition } \\
\text { - Reconstruction of a historical event }\end{array}$ \\
\hline 4. & Scenario & $\begin{array}{l}\text { - } \text { Linear (nodal plot) (Tomaszewski, 2005) } \\
\text { - Dynamics (modulated \& open plot) } \\
\quad \text { (Tomaszewski, 2005) }\end{array}$ \\
\hline 5. & Artists & $\begin{array}{l}\text { - } 3 \mathrm{D} \text { visualization } \\
\text { - } 360^{\circ} \text { panoramic photographs } \\
\text { - Interactive sound design } \\
\text { - Information: user interface and text }\end{array}$ \\
\hline 6. & Interaction & $\begin{array}{l}\text { - Immersive site exploration } \\
\text { - Depth \& detail of artefact information }\end{array}$ \\
\hline 7. & Object & $\begin{array}{l}\text { - Open museum (ex. Borobudur Temple) } \\
\text { - Historical architecture/ building (ex. Fatahilah } \\
\text { Building) } \\
\text { - Cultural Heritages (ex. Bena village, Flores) } \\
\text { - Art artefacts }\end{array}$ \\
\hline
\end{tabular}

This recommendation supports the museum curators/conservators to get preelementary information to develop VMs concepts. They, as concepts, can cooperate with programmers and artists to develop VMs. 
Virtual museums can be produced by providing gamification so that they are more attractive to users. This means that it is beneficial for learning and disseminating historical information and fun in exploring the virtual museums. Doukianou et al. (2020) state that the serious game is a game genre that can be adapted to develop a virtual museum, both as a medium of learning and the spreading of historical information.

\section{CONCLUSION}

Virtual museums in Indonesia can be developed, mainly because of the country's geography, an archipelago. This opens up opportunities to visit virtual museums remotely. In addition, virtual museums can respond to visitor needs in various ways, for example, using VR and WebGL (website-based interactive 3D visualization). These virtual museums provide an entertaining and educational experience, especially with Indonesian cultural and historical contents. In addition, the virtual museums enrich the museum exploration experience by allowing intuitive interactions with artefacts, especially for Indonesians who live on remote islands without coming to the museum.

Current technological developments in Indonesia (although not evenly distributed across regions) have accommodated the development of virtual museums. The infrastructure of the internet in Indonesia has been developed in the most remote area. Some universities and creative industries pay attention to developing educational learning interactive media, such as virtual museums. It means Indonesia has human resources that can support the development of virtual museums. They need to collaborate across disciplines between the museum curator and other related parties to produce a virtual museum.

\section{REFERENCES}

Bowen, J. P., \& Giannini, T. (2014, July 1). Digitalism: The New Realism? https://doi.org/10.14236/ewic/EVA2014.76

Direktorat Museum. (2009). Ayo Kita Mengenal Museum. Departemen Kebudayaan dan Pariwisata.

Doukianou, S., Daylamani-Zad, D., \& Paraskevopoulos, I. (2020). Beyond Virtual Museums: Adopting Serious Games and Extended Reality (XR) for UserCentred Cultural Experiences (pp. 283-299). https://doi.org/10.1007/9783-030-37191-3_15

Empler, T. (2018). Traditional museums, virtual museums. Dissemination role of ICTs. Disegnarecon, 11(21).

Ferrari, F., \& Medici, M. (2017). The Virtual Experience for Cultural Heritage: Methods and Tools Comparison for Geguti Palace in Kutaisi, Georgia. 
Proceedings, 1(10), 932. https://doi.org/10.3390/proceedings1090932

Giannini, T., \& Bowen, J. P. (2019, July 1). Art and Activism at Museums in a Postdigital World. https://doi.org/10.14236/ewic/EVA2019.4

Gutowski, P. (2019). Development of Virtual Museums in Poland. Studia Periegetica: Tourism and Recreation in the Socio-Economic and Spatial Development of Cities, 28(3(27)), 119-138. https://doi.org/10.26349/st.per.0027.07

Hereniko, V. (2018). Virtual museums and new directions? In Curatopia. Manchester University Press. https://doi.org/10.7765/9781526118202.00031

Hunicke, R., Leblanc, M., \& Zubek, R. (2004). MDA: A formal approach to game design and game research. AAAI Workshop - Technical Report, WS-04-04, $1-5$.

Kaun, A., \& Uldam, J. (2018). Digital activism: After the hype. New Media \& Society, 20(6), 2099-2106. https://doi.org/10.1177/1461444817731924

LeBlanc, M. (2004). Mechanics, Dynamics, Aesthetics: A Formal Approach to Game Design. Lecture at Northwestern University.

Maniello, D. (2016). Augmented Heritage for enhancing the cultural assets: Lights and sounds for the Nijmegen's Königorgel. Disegnarecon, 9(17), 11.111.10 .

Previtali, M. (2019). A virtual logbook for the documentation of a continuously changing archaeological site: the San Clemente site in Albenga (Italy). Virtual Archaeology Review, 10(21), 56. https://doi.org/10.4995/var.2019.11916

Schofield, G., Beale, G., Beale, N., Fell, M., Hadley, D., Hook, J., Murphy, D., Richards, J., \& Thresh, L. (2018). Viking VR. Proceedings of the 2018 Designing Interactive Systems Conference, 805-815. https://doi.org/10.1145/3196709.3196714

Sergeant, A. (2020). "Batavia": An Analysis on the Pedagogical Possibilities and Limitations of Virtual Reality Art. Journal of Integrative Research \& Reflection, 3, 47-57. https://doi.org/10.15353/jirr.v3.1683

Sylaiou, S., Liarokapis, F., Sechidis, L., Patias, P., \& Georgoula, O. (2005). Virtual Museums : First Results of a Survey on Methods and Tools. Proceedings of the CIPA and the ISPRS Conference, Torino, Italy, 1138-1143.

Tomaszewski, Z. (2005). Foundations of Interactive Narrative. http://zach.tomaszewski.name/uh/ics699/intnarr.html

Walmsley, A. P., \& Kersten, T. P. (2020). The Imperial Cathedral in Königslutter (Germany) as an Immersive Experience in Virtual Reality with Integrated $360^{\circ}$ Panoramic Photography. Applied Sciences, 10(4), 1517. https://doi.org/10.3390/app10041517

Westfries Museum. (2020). Batavia 1627 in Virtual Reality. https://wfm.nl/batavia$1627 \mathrm{vr}$ 